Artigo original

Hegemonia - Revista Eletrônica de Relações Internacionais do Centro Universitário Unieuro

ISSN: $1809-1261$

UNIEURO, Brasília, número 9, 2012, pp. 4-30.

Recebido em: 17/11/2011

Revisado em: 5/12/2011

Aprovado em: 17/12/2011

\title{
Os Refugiados no Brasil: evolução da proteção e políticas públicas
}

BEZERRA,Maria Telma ${ }^{1}$

Resumo: $O$ presente trabalho tem por intuito apresentar a evolução da proteção e os Programas de Reassentamento de Refugiados no Brasil através do Comitê Nacional para Refugiados (CONARE), ligado ao Ministério da Justiça, o Alto Comissariado das Nações Unidas para os Refugiados (ACNUR) e Organizações Não-Governamentais (ONG's) brasileiras. O Brasil é hoje um país exemplar por ter uma das legislações mais avançadas do mundo em matéria de refugiados, no momento em que tantos países adotam medidas restritivas em relação à proteção. A participação dos refugiados nos programas do governo (saúde, educação, habitação, crédito, trabalho e renda), é necessária para que tenham condições de ter uma integração social e econômica, para tanto precisam ser adotadas novas estratégias que visem à expansão de redes locais de integração, participação e direitos dos refugiados.

Palavras-chave: Refugiado. Reassentamento. Políticas Públicas.

\section{Introdução}

O refúgio é um tema tão antigo quanto à humanidade. Milhões de pessoas já tiveram que deixar seus países e buscar proteção

Mestranda em Ciência Política no UNIEURO - Centro Universitário - 70000-000 - Brasília-DF.

E-mail: telmaba55@gmail.com 
Artigo original

Hegemonia - Revista Eletrônica de Relações Internacionais do Centro Universitário Unieuro

ISSN: $1809-1261$

UNIEURO, Brasília, número 9, 2012, pp. 4-30.

internacional em outros lugares devido às perseguições por razões políticas, religiosas, sociais, culturais ou de gênero. No entanto, o refúgio na Antiguidade beneficiava, em geral, os criminosos comuns, numa inversão do que

acontece no quadro atual, pois a proteção a dissidentes políticos constituía ato de afronta entre nações que poderia gerar guerra. A pesquisa histórica reconhece que na Grécia antiga, em Roma, Egito e Mesopotâmia já existiam regras determinadas para refúgio. Naquela época, o refúgio era marcado pelo caráter religioso, oferecido nos templos e por motivo de perseguição religiosa.

Com a criação do sistema diplomático e de embaixadas, o refúgio perde esse caráter religioso e passa a ser assunto de Estado, baseado na teoria da extraterritorialidade. Hoje, a teoria da territorialidade de uma delegação diplomática foi substituída pela teoria da jurisdição. A partir da Revolução Francesa, com os ideais de liberdade e de direitos individuais, começou a se materializar a aplicação do refúgio a criminosos políticos e a extradição de criminosos comuns.

A definição legal de refugiados, conforme o artigo $1^{\circ}, \S 1^{\circ} \mathrm{da}$ Convenção de Genebra de 1951, alterada pelo Protocolo Adicional de 1967, reza sê-lo qualquer pessoa que possua temor bem fundado de perseguição por motivos de raça, religião, nacionalidade, grupo social ou opiniões políticas e se encontra fora de seu país de nacionalidade e não possa ou não queira acolher-se da proteção de tal país. Eles buscam refúgio em outros países para reconstruir suas vidas com dignidade, justiça e paz. 
Artigo original

Hegemonia - Revista Eletrônica de Relações Internacionais do Centro Universitário Unieuro

ISSN: $1809-1261$

UNIEURO, Brasília, número 9, 2012, pp. 4-30.

O ACNUR tem como função colaborar no Brasil quanto à aplicação da Convenção de 1951 sobre o Estatuto do Refugiado, bem como trabalhar com a sociedade civil e com os refugiados para facilitar seu processo de integração através de rede nacional de apoio.

A sucessiva evolução do referido estabelecimento favoreceu a origem jurídica do refúgio no século XX com vistas a oferecer proteção às pessoas atingidas em tempos de guerra, notadamente aos grandes deslocamentos populacionais após a Segunda Guerra Mundial.

\section{Os refugiados na história}

A situação dos refugiados e asilados é tão antiga como a própria história, mas a efetiva proteção aos refugiados pela comunidade internacional somente surgiu com a Sociedade de Nações. Com o fim da $1^{\text {a }}$ Guerra Mundial, o mundo viu-se diante de grandes problemas de movimentos massivos relacionados, principalmente, com a Revolução Russa e a destruição do Império Otomano. Naquele tempo, a sociedade internacional teve que encarar o problema de decidir a condição jurídica dos refugiados, organizar o assentamento ou repatriação em vários países e realizar atividades de socorro. Com a ocorrência da $2^{a}$ Guerra Mundial, o problema dos refugiados se agravou de uma forma extraordinária, com o deslocamento de milhões de pessoas por diversas partes do mundo.

Em 1943 é estabelecida a Administração das Nações Unidas para o Auxílio e Restabelecimento (ANUAR), organização que passou 
Artigo original

Hegemonia - Revista Eletrônica de Relações Internacionais do Centro Universitário Unieuro

ISSN: $1809-1261$

UNIEURO, Brasília, número 9, 2012, pp. 4-30.

a prestar auxílio para pessoas que, por motivo da guerra, precisaram se deslocar.

Em 1946, a Assembléia Geral das Nações Unidas estabeleceu os seguintes princípios, próprios da condição de refugiado:

1 - o problema dos refugiados tem alcance e caráter internacional;

2 - não se deve obrigar o regresso ao país de origem aos refugiados que expressarem objeções válidas ao retorno; 3 - um órgão internacional deveria ocupar-se do futuro dos refugiados e pessoas deslocadas; e 4 - tarefa principal consistiria em estimular o pronto retorno dos refugiados a seus países e ajudá-los por todos os meios possíveis.

Em 1947, é criada a Organização Internacional de Refugiados (OIR), para tratar dos problemas residuais dos refugiados depois da $2^{a}$ Guerra Mundial. Era o primeiro organismo internacional que se ocupava de todos os problemas dos refugiados que funcionou até 1949, quando da decisão da Assembléia Geral da Organização das Nações Unidas (ONU) de estabelecer o Alto Comissariado das Nações Unidas para os Refugiados (ACNUR) que deu início as suas atividades em 1951, especificamente após seu Protocolo de 1967, quando é verificada a preocupação da comunidade internacional em oferecer soluções de alcance global ao problema. Este órgão assumiu duas importantes funções: a de auxiliar os governos nacionais que recebessem refugiados com a integração local destes em suas novas 
Artigo original

Hegemonia - Revista Eletrônica de Relações Internacionais do Centro Universitário Unieuro

ISSN: $1809-1261$

UNIEURO, Brasília, número 9, 2012, pp. 4-30.

comunidades e a de auxiliar no repatriamento destes refugiados, desde que voluntário. (MOREIRA, 2006).

Em 28 de junho de 1951 aconteceu a Convenção Relativa ao Estatuto dos Refugiados, em Genebra, que teve por finalidade instituir quem eram as pessoas que poderiam ser designadas "refugiadas" e quais as regras que os países signatários deveriam seguir para o amparo destas pessoas. A convenção determinou como refugiado qualquer pessoa "(...) que, em conseqüência de acontecimentos ocorridos antes de 10 de Janeiro de 1951, e temendo ser perseguida por motivos de raça, religião, nacionalidade, grupo social ou opiniões políticas, se encontra fora do país de sua nacionalidade e que não pode ou, em virtude desse temor, não quer valer-se da proteção desse país, ou que, se não tem nacionalidade e se encontra fora do país no qual tinha sua residência habitual em conseqüência de tais acontecimentos, não pode ou, devido ao referido temor, não que voltar a ele. ${ }^{2}$

No ponto de vista jurídico da proteção internacional dos refugiados, a Convenção de 1951, além de garantir os direitos principais de sobrevivências e dignidade, também assegura um conjunto de direitos civis e socioeconômicos. É o que afirma James C. Hathaway:

While falling short of the comprehensive list of civil rights promoted by the Universal Declaration of The Human Rights,

CONVENÇÃO DE 1951: Convenção relativa ao estatuto dos refugiados. IN: ARAUJO, Nádia de; ALMEIDA, Guilherme Assis de (Coord.) O Direito Internacional dos Refugiados: uma perspectiva brasileira. Rio de Janeiro: Renovar, 2001. 
Artigo original

Hegemonia - Revista Eletrônica de Relações Internacionais do Centro Universitário Unieuro

ISSN: $1809-1261$

UNIEURO, Brasília, número 9, 2012, pp. 4-30.

the Refugee Convention nonetheless pays significantly more attention to the definition of a sphere of personal freedom for refugees than did any of the earlier refugee agreements. The inability of states to make any reservations to their obligation to guarantee protection against discrimination, religious freedom, and access to the courts entrenches a universal minimum guarantee of basic liberties for refugees.

Of particular importance are the guarantees of key socioeconomic rights that integrate refugees in the economic system of the country of asylum or settlement, enabling them to provide for their own needs. Basic rights to property and work are supplemented by a guarantee of access to the asylum country's social safety net. Refugees are also to be treated as citizens under labor and tax legislation. ${ }^{3}$

Em meio aos direitos citados na Convenção, havia duas limitações: uma de caráter temporal e outra de caráter geográfico, suprimidas pelo Protocolo Adicional de 1967. Trata-se de uma Convenção direcionada e datada, escrita após a Segunda Guerra Mundial para resolver $o$ problema de refugiados que ali se apresentava.

No Brasil, o regime jurídico dos refugiados somente foi adotado em 22 de julho de 1997, quando publicada a Lei Ordinária no 9474, que criou o Comitê Nacional dos Refugiados (CONARE), embora o Brasil já recebesse refugiados há algum tempo, por meio de acordos entre o Governo Federal e o ACNUR, apoiado pela organização internacional Cáritas Arquidiocesanas.

\footnotetext{
Enquanto não atenta à significativa lista de direitos civis proclamados pela Declaração Universal dos Direitos Humanos, a Convenção sobre Refugiados, entretanto, presta significativamente mais atenção à definição de uma esfera de liberdades pessoais para os refugiados, do que havia feito qualquer dos acordos anteriores sobre refugiados. A inabilidade dos Estados em fazer concessões às suas obrigações de garantir proteção contra discriminação, liberdade religiosa e acesso às Cortes contrapõe-se frontalmente a uma garantia mínima universal de liberdades básicas aos refugiados. HATHAWAY, James C. The rights of refugees under International Law. Cambridge: Cambridge University Press, 2005. P. 94-95. (tradução livre).
} 
Artigo original

Hegemonia - Revista Eletrônica de Relações Internacionais do Centro Universitário Unieuro

ISSN: $1809-1261$

UNIEURO, Brasília, número 9, 2012, pp. 4-30.

O artigo $1^{0}$ do Protocolo de 1967, Relativo ao Estatuto dos Refugiados ampliou o alcance da norma, assim considerando:

Art. $1^{0} \S 20$ "Para os fins do presente Protocolo, o termo "refugiado", salvo no que diz respeito à aplicação do $\S 3^{\circ}$ do presente artigo, significa qualquer pessoa que se enquadre na definição dada no artigo primeiro da Convenção, como se as palavras "em decorrência dos acontecimentos ocorridos antes de $1^{0}$ de janeiro de $1951 \ldots$.., e as palavras "... como conseqüência de tais acontecimentos" não figurassem do $\S 2^{\circ}$ da seção $A$ do artigo primeiro.

O presente Protocolo será aplicado pelos Estados Membros sem nenhuma limitação geográfica; entretanto, as declarações já feitas em virtude da alínea "a" do $\S 10$ da seção B do artigo10 da Convenção aplicar-se-ão, também, no regime do presente Protocolo, a menos que as obrigações do Estado declarante tenham sido ampliadas de conformidade com o $\S 2^{\circ}$ da seção B do artigo $1^{\circ}$ da Convenção. ${ }^{4}$

O Brasil, em 1960, foi o primeiro país do Cone Sul a ratificar a Convenção de 1951 relativa ao Estatuto dos Refugiados. Em 1997, foi também o primeiro país da região a sancionar uma Lei Nacional de Refúgio. Em 1998, criou o Comitê Nacional para os Refugiados (CONARE), órgão de deliberação coletiva, que concede às pessoas, reconhecidas como refugiados, documentação que lhes permite residir legalmente no país, trabalhar e ter acesso aos serviços de

ACNUR. Protocolo de 1967, relativo ao Estatuto dos Refugiados. In: Lei 9747/97 e Coletânea de Instrumentos de Proteção Internacional dos Refugiados. ACNUR: Brasília, 2005. p.65-66. 
Artigo original

Hegemonia - Revista Eletrônica de Relações Internacionais do Centro Universitário Unieuro

ISSN: $1809-1261$

UNIEURO, Brasília, número 9, 2012, pp. 4-30.

saúde e educação, vinculado ao Ministério da Justiça, que tem a finalidade de conduzir a política nacional sobre os refugiados e em parceria com organizações não-governamentais em diversos estados, entre elas a Associação Antônio Vieira (no Rio Grande do Sul), as Cáritas Arquidiocesanas nas cidades do Rio de Janeiro, São Paulo e Manaus, o Instituto Migrações e Direitos Humanos (no Distrito Federal) e o Centro de Defesas dos Direitos Humanos de Guarulhos, no interior de São Paulo, (Barreto, 2001)5.

Aliado a Venezuela, o Brasil foi um dos primeiros países integrantes do Comitê Executivo do ACNUR, que é composto pelos países que têm demonstrado o maior grau de compromisso com a temática dos refugiados. O comitê aprova os programas e orçamentos anuais do ACNUR.

De acordo com as informações do CONARE, até junho de 2011, o Brasil reconheceu 4.418 refugiados de 77 nacionalidades diferentes (cerca de $10 \%$ pelo seu Programa de Reassentamento Solidário), a maioria dos refugiados vive no Rio de Janeiro e São Paulo. Os africanos representam $64 \%$ dos refugiados no Brasil, sendo os angolanos a principal população, os colombianos $14 \%$ e congoleses da República Democrática do Congo 10\%.

Após o terremoto de 2010, a busca de asilo no Brasil pelos haitianos aumentou muito, embora não se enquadrando na definição

Luiz Paulo Teles F. Barreto é Secretário-Executivo do Ministério da Justiça, ex-diretor do Departamento de Estrangeiros, da Secretaria Nacional de Justiça e Presidente do Comitê Nacional para os Refugiados. 
Artigo original

Hegemonia - Revista Eletrônica de Relações Internacionais do Centro Universitário Unieuro

ISSN: $1809-1261$

UNIEURO, Brasília, número 9, 2012, pp. 4-30.

clássica de refugiados - dada a quem é efetivamente a sair de seu país de origem devido a fundados temores de perseguição por motivos de raça, religião, nacionalidade, grupo social ou opinião pública-, eles entravam com o pedido para que o governo brasileiro os considerasse dessa maneira. O governo decidiu pela legalização de alguns desses imigrantes fornecendo um visto humanitário, tomando todas as precauções, checando se entre os solicitantes não havia criminosos procurados pela polícia.

As definições e distinções entre asilo e refúgio

Muito antes da formação dos Estados Nacionais, os impérios já praticavam o direito de asilo aos fugitivos, perseguidos e criminosos. A normatização desse instituto surge com a aprovação da Declaração Universal dos Direitos Humanos de 1948, inspirada pela Revolução Francesa, nos princípios de liberdade, igualdade, fraternidade e solidariedade, afirma em seu artigo 14:

Toda pessoa vítima de perseguição tem o direito de procurar e de gozar asilo em outros países.

Esse direito não pode ser invocado em caso de perseguição legitimamente motivada por crime de direito comum ou por atos contrários aos objetivos e princípios das Nações Unidas.

Embora garantido esse direito pela Declaração Universal da ONU, não obrigava os Estados a conceder o asilo. De acordo com Celso Mello, que corrobora com a afirmação anterior: "Não existe qualquer obrigatoriedade do Estado em conceder o asilo. A sua concessão é um ato discricionário do Estado asilante. O asilo é um direito do Estado e não do indivíduo". ${ }^{6}$

MELLO, Celso D. de Albuquerque. Curso de Direito Internacional Público. 15 ed. rev. ampl. vl. 2. Renovar. Rio de Janeiro, 2004. p.1101. 
Artigo original

Hegemonia - Revista Eletrônica de Relações Internacionais do Centro Universitário Unieuro

ISSN: $1809-1261$

UNIEURO, Brasília, número 9, 2012, pp. 4-30.

No entender de Flávia Piovesan, a Declaração asseguraria o direito de asilo como direito fundamental de todos os seres humanos que são perseguidos. Para ela, o advento dos termos da Declaração constitui-se um grande avanço, vejamos:

Ao salientar os contornos do direito de asilo, percebe-se que a Declaração assegura o direito fundamental de toda pessoa de estar livre de qualquer forma de perseguição. Consequentemente, na hipótese de perseguição decorre o direito fundamental de procurar e gozar asilo em outros países. A perseguição a uma pessoa caracteriza grave violação aos direitos humanos. Vale dizer, cada solicitação de asilo é resultado de um forte padrão de violência a direitos universalmente garantidos. ${ }^{7}$

Como regra geral, o asilo apresenta-se com a finalidade de proteger todas as pessoas que fossem perseguidas. $O$ procedimento adotado para a concessão do asilo não se apresentava mais satisfatório, fazia-se necessário a criação de um estatuto exclusivo que regulamentasse a situação das pessoas que migravam de seus territórios.

$\mathrm{Na}$ América Latina, desenvolveu-se o conceito de asilo, originário do Tratado de Direito Penal Internacional de Montevidéu, de 1889, que dedicou um capítulo ao tema. Várias convenções aconteceram no continente americano, voltadas à temática do asilo, bem como a Convenção sobre Asilo assinada na VI Conferência Panamericana de Havana, em 1928; a Convenção sobre Asilo Político da

PIOVESAN, Flávia. O direito de asilo e a proteção internacional dos refugiados. In: ARAÚJO, Nádia de; ALMEIDA, Guilherme Assis de (Coord.). O Direito Internacional dos Refugiados: uma perspectiva brasileira. Rio de Janeiro. Renovar, 2001. p.30. 
Artigo original

Hegemonia - Revista Eletrônica de Relações Internacionais do Centro Universitário Unieuro

ISSN: $1809-1261$

UNIEURO, Brasília, número 9, 2012, pp. 4-30.

VII Conferência Internacional Americana de Montevidéu, em 1933; o Tratado sobre Asilo e Refúgio Político de Montevidéu, em 1939; e a Convenção sobre Asilo Diplomático da X Conferência Interamericana de Caracas, em 1954.

O asilo diplomático é instituto característico da América Latina, sempre foi largamente praticado, possivelmente pela instabilidade política na região, com revoluções e golpes de estado, portanto há necessidade de se conceder proteção aos chamados criminosos políticos. Também poderá ser concedido nas legações, nos navios, aeronaves e acampamentos militares.

Em outros lugares do mundo, a expressão utilizada é refúgio. É evidente, que outros países aplicam o asilo diplomático casualmente, não o reconhecendo, como instituto de Direito Internacional.

Porém, um estrangeiro que procura abrigo em missão diplomática, e o país não estando interessado a permitir-lhe o asilo territorial, pode ser conduzido a outro Estado que o aceite. $O$ asilo territorial depende de normas internas e precisa da solicitação no lugar de jurisdição do Estado concedente.

No sentido jurídico do termo, o refúgio surgiu no âmbito da Liga das Nações em 1921, como um problema simples durante e após a Primeira Guerra Mundial, quando os exércitos inimigos avançavam, enviando um grande número de pessoas para além de suas fronteiras nacionais, especialmente européias. Os regimes aplicavam políticas de eliminação da nacionalidade a grupos minoritários ou de origem específica, privando-os da proteção jurídica existente.

A principal diferença entre os institutos jurídicos do asilo e do refúgio reside no fato de que o primeiro constitui exercício de um ato 
Artigo original

Hegemonia - Revista Eletrônica de Relações Internacionais do Centro Universitário Unieuro

ISSN: $1809-1261$

UNIEURO, Brasília, número 9, 2012, pp. 4-30.

soberano do Estado, cujo cumprimento não se sujeita a nenhum organismo internacional. Enquanto que refúgio, como uma instituição convencional de caráter universal, visa a proteção de pessoas com fundado temor de perseguição.

Uma diferença prática de fácil visão é que o asilo normalmente é empregado em casos de perseguição política individualizada. $O$ refúgio é aplicado a casos em que a necessidade de proteção atinge a um número alto de pessoas, onde a perseguição tem aspecto mais generalizado.

A Constituição Federal do Brasil de 1988, artigo 40 inciso X, rege-se nas suas relações internacionais, pelos princípios da "prevalência dos direitos humanos e da concessão do asilo político". O asilo político é tratado, ainda, em título próprio da Lei no 6.815 , de 1980, O Estatuto do Estrangeiro, que dispõe que o estrangeiro admitido no território nacional na condição de asilado político ficará sujeito, além dos deveres que Ihe forem impostos pelo Direito Internacional, a cumprir as disposições da legislação vigente e as que o governo brasileiro Ihe fixar.

Em 1951, publica-se a Convenção relativa ao Estatuto dos Refugiados, a qual estabelece os critérios para definir aqueles que se enquadram no conceito por ela esboçado, constante em seu artigo $1^{\circ}$, $\S 10$ :

Para os fins da presente Convenção, o termo "refugiado" se aplicará a qualquer pessoa

[...]

Que, em conseqüência dos acontecimentos ocorridos antes de $1^{\circ}$ de janeiro de 1951 e temendo ser perseguida por motivos de raça, religião, nacionalidade, grupo social ou opiniões políticas, se encontra fora do país de sua nacionalidade e que não pode ou, em virtude desse temor, não quer valer-se da proteção desse país, ou que, se não 
Artigo original

Hegemonia - Revista Eletrônica de Relações Internacionais do Centro Universitário Unieuro

ISSN: $1809-1261$

UNIEURO, Brasília, número 9, 2012, pp. 4-30.

tem nacionalidade e se encontra fora do país no qual tinha sua residência habitual em conseqüência de tais acontecimentos não pode ou, devido ao referido temos, não quer voltar a ele. ${ }^{8}$

Ao referir-se a "asilo" tratar-se-á da proteção concedida a todos aqueles que necessitam de abrigo em outro Estado pelos mais diversos motivos. Ao referir-se a "refúgio" tratar-se-á da espécie, considerando todos aqueles indivíduos que buscam proteção pelos motivos apontados nas convenções que tratam do tema.

Segundo análise de Jaime Ruiz de Santiago :

[...] el asilo es una institución que nació como protección frente a uma persecución, La que debe ser actual y presente,contra una persona, lo que se refleja en el Art. II de la Convención sobre Asilo Territorial de Caracas (1954).

[...] el refúgio, por el contrário, es menos riguroso al respecto, pues no requiere de una actual y efectiva persecución y le es suficiente "el fundado temor de perseguición. ${ }^{9}$

Acerca das diferenciações existentes, tanto o gênero asilo, como todas as suas espécies possuem um objetivo comum: a proteção da vida, da liberdade e da dignidade da pessoa humana.

ACNUR. Convenção de 1951, relativa ao Estatuto dos Refugiados. In: Lei 9747/97 e Coletânea de Instrumentos de Proteção Internacional dos Refugiados. ACNUR. Brasília, 2005. p.44.

[...] o asilo é uma instituição que nasce como proteção frente a uma perseguição, a qual deve ser atual e presente, contra uma pessoa, o que se reflete no artigo II da Convenção sobre Asilo Territorial de Caracas (1954).

[...] o refúgio, ao contrário, é menos rigoroso a esse respeito, pois não requer uma atual e efetiva perseguição e o é suficiente "o fundado temor de perseguição". SANTIAGO, Jaime Ruiz de. Temas relevantes del Derecho Internacional de los Refugiados com respecto al problema de los refugiados en América Latina. Revista do Instituto Brasileiro de Direitos Humanos. Fortaleza: v. 1. nº 1, 1999, p.56. 
Artigo original

Hegemonia - Revista Eletrônica de Relações Internacionais do Centro Universitário Unieuro

ISSN: $1809-1261$

UNIEURO, Brasília, número 9, 2012, pp. 4-30.

\section{O Princípio do Non-Refoulement}

Essa definição estabelece aos Estados Membros da Convenção de 1951 e do Protocolo de 1967 a cumprirem com os princípios que exercem o Direito Internacional dos Refugiados, como os princípios do "non-refoulement", ou não-devolução, o qual proíbe o retorno forçado de refugiado ao país de onde este veio, ou para no qual ele possa sofrer perseguição; o princípio da dignidade da pessoa humana; bem como propiciar aos refugiados os mesmos direitos e a assistência básica que qualquer outro estrangeiro residente legal tenha que é a liberdade de ir e vir, a liberdade de pensamento, a proteção contra a tortura e outras formas de tratamentos ofensivos, os direitos econômicos e sociais, a saúde, a educação e o trabalho.

Com referência ao princípio do "non-refoulement", confirma Flávia Piovesan:

Dentre os direitos protegidos, merece destaque o direito do refugiado de não ser devolvido, que constitui um princípio basilar do sistema de proteção de refugiados. À luz do princípio da não-devolução, ninguém pode ser obrigado a retornar a um país em que sua vida e liberdade estejam ameaçadas. Esse direito é consagrado no artigo $33 \mathrm{da}$ Convenção de 1951, quando afirma que "nenhum dos Estados contratantes expulsará ou repelirá um refugiado, seja de que maneira for, para as fronteiras dos territórios onde a sua vida ou a sua liberdade sejam ameaçadas em virtude de sua raça, religião, nacionalidade, filiação em certo grupo social ou opiniões políticas". O princípio do nonrefoulement é, assim, um princípio geral tanto do Direito dos Refugiados como do Direito dos Direitos Humanos, devendo ser reconhecido e respeitado como um princípio de jus cogens. ${ }^{10}$

O termo latino jus cogens refere-se a uma norma imperativa de Direito Internacional, ou seja, aquela que deve ser respeitada, mesmo que os Estados não façam parte dos tratados que trazem tal norma explicitamente. É esse também o entendimento expresso na Conclusão quinta da Declaração de Cartagena de 1984. Aduz citada conclusão que se deve: "Reiterar a importância e a significação do princípio de non-refoulement (incluindo a proibição da rejeição nas fronteiras), como pedra angular da proteção internacional dos refugiados. Este princípio imperativo respeitante aos refugiados deve reconhecer-se e respeitar-se no estado atual do direito internacional como um princípio de jus-cogens". (grifou-se) In: Lei 
Artigo original

Hegemonia - Revista Eletrônica de Relações Internacionais do Centro Universitário Unieuro

ISSN: $1809-1261$

UNIEURO, Brasília, número 9, 2012, pp. 4-30.

A desobediência ao cumprimento desse princípio pode implicar em responsabilidade do Estado, pela violação não só de um princípio do Direito Internacional dos Refugiados, mas um princípio de Direito Internacional, colocando os refugiados rejeitados em situação de perigo ou de perseguição.

\section{ACNUR : características e funções}

O Alto Comissariado das Nações Unidas para Refugiados (ACNUR) foi criado pela Assembléia Geral das Nações Unidas, através das resoluções 319 (IV), de 3 de dezembro de 1949 e 428 (V) de 14 de dezembro de 1950. O ACNUR nasceu como uma agência temporária, com um mandato pautado pelos princípios de proteger os refugiados e promover soluções duradouras para seus problemas. No entanto, o ACNUR foi convocado a continuar seu trabalho e rebater as crises de refugiados em todo o mundo, acompanhando as mudanças apresentadas.

Sua função traduz-se na proteção jurídica, na assistência material aos que precisam do refúgio, na reorganização das vidas das pessoas, oferecendo a proteção à vida, à dignidade e à segurança dos refugiados, impedindo que haja violações aos seus direitos humanos fundamentais e fiscalizando os Estados membros da Convenção de 2005. 
Artigo original

Hegemonia - Revista Eletrônica de Relações Internacionais do Centro Universitário Unieuro

ISSN: $1809-1261$

UNIEURO, Brasília, número 9, 2012, pp. 4-30.

1951 e do Protocolo de 1967 se estão cumprindo com suas obrigações para com os refugiados.

Entre os programas implementados estão o de integração local, que busca facilitar a inserção do refugiado na comunidade, e o de reassentamento, que recebem refugiados que continuam sofrendo ameaças e problemas de adaptação no primeiro país de refúgio.

No Brasil, o ACNUR atua em cooperação com o Comitê Nacional para os Refugiados (CONARE), ligado ao Ministério da Justiça. Além da proteção física e legal, os refugiados no país têm direito à documentação e aos benefícios das políticas públicas de educação, saúde e habitação, entre outras. Para garantir a assistência humanitária e a integração dessa população, o ACNUR também trabalha com diversas ONGs no país.

Em parceria com o poder público e a sociedade civil, o ACNUR apoia a integração local dos refugiados que se encontram em território brasileiro - e a garantia de seus direitos - por meio do reforço às redes de apoio da sociedade civil, da promoção de atividades de geração de renda voltadas para a autossuficiência e da inserção em programas sociais e políticas públicas.

\section{A segurança}

Uma situação delicada é a ausência de segurança para os refugiados que vivem sob tensões, principalmente os que se encontram em campos próximos das fronteiras, por não possuírem meios materiais nem humanos para garantir essa proteção. 
Artigo original

Hegemonia - Revista Eletrônica de Relações Internacionais do Centro Universitário Unieuro

ISSN: $1809-1261$

UNIEURO, Brasília, número 9, 2012, pp. 4-30.

De acordo com o relato da ACNUR a respeito dessas dificuldades de garantir segurança aos refugiados, admite que as ameaças à segurança física dos refugiados têm as mais diversas origens, entre elas está o crime organizado, as forças policiais e paramilitares, combatentes antigovernamentais, populações locais e até mesmo a própria comunidade de refugiados. As ameaças físicas vão desde o roubo, a agressão e a violência doméstica até o abuso infantil, a violação e o tráfico de pessoas. A vulnerabilidade aumenta quando os refugiados possuem recursos econômicos limitados e suas estruturas familiares e comunitárias foram destruídas ou sofreram ameaças.

A causa da segurança é uma questão política, que abrange toda a comunidade de Estados das Nações Unidas e que precisa ser tratada com mais acuidade.

Uma das últimas formas do ACNUR, no sentido de assegurar a segurança dos refugiados, foi criar medidas preventivas e corretivas, auxiliado pelos organismos nacionais de aplicação da lei, conjuntamente com os Estados e com a comunidade internacional.

Outra preocupação envolvendo os refugiados é o problema da violência sexual e de gênero, tendo como principais alvos as mulheres e as meninas, que obrigadas a deixarem seus lares são expostas ao abuso sexual pelos seus provedores.

A fuga que os levam a buscarem asilo em outros locais, pelo impulso da sobrevivência, não imaginam a dimensão do problema que pode acontecer. Muitas crianças são separadas de seus pais ou perdem-se, capturadas por grupo militares que as recrutam, são escravizadas e obrigadas a trabalharem como soldados. Além disso, 
Artigo original

Hegemonia - Revista Eletrônica de Relações Internacionais do Centro Universitário Unieuro

ISSN: $1809-1261$

UNIEURO, Brasília, número 9, 2012, pp. 4-30.

são ainda violentadas sexualmente, sofrem torturas e maus tratos, as meninas sofrem mutilações (genital), sofrem fome, são acometidas de doenças e muitas vezes obrigadas a assistirem atos de torturas e violências contra seus familiares.

Muitas crianças, quando permitido o direito à educação, são discriminadas por seus companheiros de grupo, os quais, muitas vezes, estimulados pelos próprios educadores a tomarem essa atitude. A maioria dos países ainda não desenvolveu critérios, sistemas e programas de proteção aos menores vulneráveis, rejeitados e esquecidos, a fim de evitar que sejam mandados de volta ao lugar de origem de onde fugiram.

$O$ reassentamento

Na ausência da repatriação voluntária e a integração local, uma das soluções duradouras identificadas pelo ACNUR como proteção dos refugiados, o reassentamento é a solução adequada. A caracterização do reassentamento dá-se pela transferência de refugiados que já se acham sob a proteção de um país, para um terceiro país, por razões de sua liberdade, sua vida, sua segurança, seus direitos humanos fundamentais continuarem em risco no país onde solicitaram e receberam refúgio pela primeira vez.

Atualmente, existem 24 países ${ }^{11}$ com programas regulares de reassentamento estabelecidos, cujas características e critérios distinguem-se consideravelmente, a depender de diversos fatores

Argentina, Austrália, Brasil, Bulgária, Canadá, Chile, Dinamarca, Espanha, Estados Unidos, Finlândia, França, Holanda, Islândia, Irlanda, Japão, Noruega, Nova Zelândia, Paraguai, Portugal, Reino Unido, Romênia, Suécia, República Tcheca e Uruguai. 
Artigo original

Hegemonia - Revista Eletrônica de Relações Internacionais do Centro Universitário Unieuro

ISSN: $1809-1261$

UNIEURO, Brasília, número 9, 2012, pp. 4-30.

como: recursos financeiros e humanos alocados; legislação; cotas anuais de recepção; política de Estado; aceitação e envolvimento da sociedade no processo de acolhida e integração; estágio de desenvolvimento da rede de proteção social disponível para os demais cidadãos.

De acordo com as estimativas no relatório de Projeção das Necessidades Globais de Reassentamento 2011, o ACNUR estima que a cada 100 refugiados em necessidade de reassentamento, apenas 10 deles são reassentados por ano. O reassentamento não é um direito dos refugiados, mas é uma perspectiva de solução duradoura que depende unicamente do asilo de países receptores em liberar suas fronteiras àquelas pessoas em necessidade de proteção em um terceiro pais. Conclui-se que o reassentamento tem vinculação com a necessidade de proteção e não com a vontade de um indivíduo em ser reassentado.

No Brasil, o reassentamento já estava previsto desde a criação da Lei 9.474/97, expresso no Artigo 46 onde se ê: "O reassentamento de refugiados no Brasil se efetuará de forma planificada e com a participação coordenada dos órgãos estatais e, quando possível se organizações não-governamentais, identificando áreas de cooperação e de determinação de responsabilidades". Em 1999, é celebrado o Acordo Macro para Reassentamento de Refugiados estabelecido entre governo da República Federativa do Brasil e o Alto Comissariado das Nações Unidas para os Refugiados. $\mathrm{Na}$ descrição do seu objetivo, o Acordo Macro reconhece que o "reassentamento é um instrumento importante de proteção aos refugiados, na busca de soluções duradouras", vislumbrando a 
Artigo original

Hegemonia - Revista Eletrônica de Relações Internacionais do Centro Universitário Unieuro

ISSN: $1809-1261$

UNIEURO, Brasília, número 9, 2012, pp. 4-30.

implementação de um projeto piloto voltado para a recepção de refugiados originários da ex-iugoslávia.

Em novembro de 2000, o escritório regional do ACNUR em Buenos Aires, contratou um consultor de reassentamento com 0 objetivo de planejar e implementar os programas de reassentamento no Brasil, Chile e Argentina, tendo em conta o envolvimento dos governos e organizações da sociedade civil organizada.

Em março de 2001, houve uma missão do ACNUR às cidades previamente selecionadas pelo Ministério da Justiça, para a implementação desse projeto, tendo como regras extensão geográfica, atividades econômicas e origem étnica da população.

Em abril de 2002, com a chegada de 23 refugiados afegãos vindos de um refúgio na Índia e Irã, aconteceu a primeira experiência de reassentamento no Brasil. Com a extinção dos motivos que geraram a fuga do país de origem, muitos deles optaram pela repatriação voluntária ao Afeganistão. A segunda experiência se deu em setembro de 2003, com a chegada de 16 refugiados colombianos vindo da Costa Rica, reassentados no Rio Grande do Sul.

Em novembro de 2004, governos e representantes da sociedade civil de 20 países latino- americanos se reuniram no México para comemorar o $20^{\circ}$ aniversário da Declaração de Cartagena sobre Refugiados e definir uma resposta conjunta e compartilhada ao novo panorama da região em termos de refugiados e deslocados internos. O chamado Plano de Ação do México define prioridades de proteção e estratégias em torno de soluções duradouras para os refugiados na América Latina. 
Artigo original

Hegemonia - Revista Eletrônica de Relações Internacionais do Centro Universitário Unieuro

ISSN: $1809-1261$

UNIEURO, Brasília, número 9, 2012, pp. 4-30.

Para compartilhar as responsabilidades da proteção aos refugiados na América Latina, o governo brasileiro propôs, em agosto de 2004, um programa regional de Reassentamento Solidário. Por meio desta iniciativa, países como Brasil, Argentina, Chile, Paraguai e Uruguai passaram a receber refugiados, principalmente colombianos, que se encontravam em países da região. O programa teve como enfoque específico o conflito colombiano, no qual o Brasil reassentou 291 refugiados nos estados do Rio Grande do Sul, São Paulo e Rio Grande do Norte.

Desde então, o número de refugiados reassentados no Brasil vem crescendo e os programas de proteção e assistência têm se aperfeiçoado, oferecendo soluções inovadoras - acesso ao microcrédito e a programas de habitação local, por exemplo - que facilitam a autossuficiência e a integração dos beneficiários. De acordo com estatística do CONARE em 31/12/2010, cerca de 407 refugiados reassentados vivem no país.

O Brasil é hoje um país de referência para o reassentamento e, numa postura humanitária e emergencial, em 2007, acolheu 108 refugiados palestinos vindos do Iraque que viviam por quatro anos em um campo na Jordânia, sob as mais diversas condições climáticas e de estrutura física e social, sem fazer qualquer distinção quanto à idade, nível educacional, doença pré-existente ou antecedentes criminais. O grupo foi reassentado nos estados do Rio Grande do Sul e de São Paulo, pelo fato da existência de parceiros implementadores experientes e de uma comunidade árabe-palestina próspera e bem estabelecida nas duas localidades. 
Artigo original

Hegemonia - Revista Eletrônica de Relações Internacionais do Centro Universitário Unieuro

ISSN: $1809-1261$

UNIEURO, Brasília, número 9, 2012, pp. 4-30.

O papel dos atores envolvidos no programa de reassentamento brasileiro podem ser contemplados no item 9.1 do Acordo Macro, onde se encontra que:

"o Governo do Brasil será responsável pela recepção e facilitará a integração dos refugiados reassentados, contando com o apoio do ACNUR e de organizações governamentais ou não governamentais. O ACNUR contribuirá financeiramente com a integração dos refugiados por meio de um projeto no qual se designará a entidade executora. Tal projeto será executado por tal entidade, em coordenação com o ACNUR".

Também as corporações (Nike e Microsoft) são parceiras oficias do ACNUR, reassentando refugiados nos países onde tais empresas possam empregá-los, auxiliando-os ainda a estudarem no tempo livre. Empresários enviam seus funcionários para entrarem em contato com refugiados e analisarem suas habilidades, com intenção em contratá-los, reassentando-os nos países onde tais empresas o empregarão.

Os refugiados e o meio ambiente

A situação ambiental, muitas vezes provocada pela irracionalidade do homem, torna necessária a mudança em massa do ser humano para outros lugares. Verifica-se que essas alterações ambientais levam a um maior número de pessoas a procurarem asilo em outro lugar. Há, porém outro fator que são os impactos causados pelos grandes acampamentos de refugiados. Muitas vezes esse assunto não é priorizado em razão de outros mais urgentes como a segurança, a alimentação e a saúde, embora nos últimos anos tem-se desenvolvido uma conscientização sobre a necessidade da abordagem e implementação de melhoramentos ambientais nesses lugares.

Essas ações previnem a destruição ecológica do local, no sentido de levar informações de como utilizar de forma racional e 
Artigo original

Hegemonia - Revista Eletrônica de Relações Internacionais do Centro Universitário Unieuro

ISSN: $1809-1261$

UNIEURO, Brasília, número 9, 2012, pp. 4-30.

sustentável o ambiente que os cerca. Educar essas pessoas pela sua própria segurança, para que não seja ignorada a prevenção, a moradia em desertos, à beira de vulcões, não desmatem áreas de preservação, não cacem animais em extinção, que mantenham os cuidados e resistência ao meio às adversidades que Ihes são impostas. A questão do racismo e da xenofobia

Algumas comunidades observam os refugiados como uma ameaça à sua segurança, à estabilidade nacional, à prosperidade econômica, à sua identidade cultural ou até mesmo como rivais na busca por recursos naturais, às vezes precários, podendo causar um forte impacto político e econômico. A maioria dos grupos sociais tende a desconfiar e a hostilizar o estrangeiro, motivado pelo medo, por causa de discriminação racial ou preconceito. Com muita frequência são alvos de discussões sócio-econômicas, acusados como razão principal de desequilíbrios sociais e econômicos enfrentados pelos países.

Os refugiados podem sofrer também limitações no acesso ao emprego devido seu histórico migratório e terem seus direitos mais simples negados, como o de praticar sua religião, ter acesso ao sistema de ensino e de se movimentar livremente pelo território de acolhida.

Diante desses problemas, o ACNUR, unido a outras organizações internacionais, tem realizado um trabalho em conjunto no combate ao racismo e xenofobia que devem ser extintas com respeito às desigualdades e igualdade entre os nacionais e refugiados e identificação de refugiados em necessidade de reassentamento. Políticas públicas 
Artigo original

Hegemonia - Revista Eletrônica de Relações Internacionais do Centro Universitário Unieuro

ISSN: $1809-1261$

UNIEURO, Brasília, número 9, 2012, pp. 4-30.

Além da proteção física e legal, os refugiados no Brasil têm direito à documentação e aos benefícios das políticas públicas de educação, saúde e habitação, entre outras. Para garantir a assistência humanitária e a integração dessa população, o ACNUR também trabalha com diversas ONGs no país.

As ações da parceria ACNUR / Cáritas São Paulo são implementadas no contexto do marco jurídico brasileiro, a lei 9.474 (de 1997), que incorpora as garantias e avanços do Estatuto dos Refugiados de 1951, do Protocolo de 1967 e da Declaração de Cartagena de 1984. A legislação brasileira considera também grave e generalizada violação dos direitos humanos como um critério para o reconhecimento do refúgio. Os refugiados contam com programas de integração social, cultural, legal e econômica, assim como encaminhamentos para o mercado de trabalho.

Tanto nos casos de asilo, quanto nos de refúgio, ao estrangeiro é fornecido documento de identidade e carteira de trabalho, ficando assegurado o exercício de todos os direitos civis de um estrangeiro residente no País.

A participação dos refugiados nos programas do governo (saúde, educação, habitação, crédito, trabalho e renda), são necessárias para que tenham condições de ter uma integração social e econômica, para tanto precisam ser adotadas novas estratégias que visem a expansão de redes locais de integração, participação e direitos dos refugiados.

O ACNUR arca com os gastos de medicamentos essenciais, exames médicos e tratamentos específicos quando necessário. As mulheres têm acesso aos serviços especializados e recebe orientação 
Artigo original

Hegemonia - Revista Eletrônica de Relações Internacionais do Centro Universitário Unieuro

ISSN: $1809-1261$

UNIEURO, Brasília, número 9, 2012, pp. 4-30.

sobre DST/AIDS, planejamento familiar, cuidados pré-natais e pósnatais.

Os refugiados têm acesso ao sistema de educação pública tanto no nível primário quanto no secundário. Todos os refugiados em idade escolar estão regularmente matriculados.

São organizados cursos de língua portuguesa em cooperação com instituições locais. Assim, todos os beneficiários cuja língua materna não seja o português terão a oportunidade de aprender o idioma e melhor se integrar à sociedade brasileira. São firmadas também parcerias com outras instituições para capacitação profissional dos refugiados.

O SENAI- Serviço Nacional de Aprendizagem da Industria e o SESI - Serviço Social da Indústria, oferecem aos refugiados cursos de capacitação profissional, além de outros serviços como ensino fundamental, escola para crianças e atividades esportivas; o SENAC Serviço Nacional de Aprendizagem Comercial e o SESC - Serviço Social do Comércio oferecem cursos de português, tratamento odontológico, atividades esportivas e alimentação - a 40\% do custo total - aos refugiados; a OAB colabora no atendimento jurídico e na divulgação do direito internacional do Refugiado.

Em parceria com o poder público e a sociedade civil, o ACNUR apoia a integração local dos refugiados que se encontram em território brasileiro - e a garantia de seus direitos - por meio do reforço às redes de apoio da sociedade civil, da promoção de atividades de geração de renda voltadas para a autossuficiência e da inserção em programas sociais e políticas públicas. O poder da população civil organizada, canalizado através auxílio de ensino, de 
Artigo original

Hegemonia - Revista Eletrônica de Relações Internacionais do Centro Universitário Unieuro

ISSN: $1809-1261$

UNIEURO, Brasília, número 9, 2012, pp. 4-30.

defesa de celebridades e de associações esportivas, pode promover o entendimento, conscientizar o público e melhorar a vida dos refugiados nos campos.

Entre os programas implementados estão o de integração local, que busca facilitar a inserção do refugiado na comunidade, e o de reassentamento, que recebe refugiado que continuam sofrendo ameaças e problemas de adaptação no primeiro país de asilo.

\section{Referências}

ACNUR. Convenção de 1951, relativa ao Estatuto dos Refugiados. In: Lei 9747/97 e Coletânea de Instrumentos de Proteção Internacional dos Refugiados. Brasília, 2005.

.Lei 9747/97 e Coletânea de Instrumentos de Proteção Internacional dos Refugiados. Brasília, 2005.

ARAÚJO, Nádia de; ALMEIDA, Guilherme Assis de (Coord.) O Direito Internacional dos Refugiados: uma perspectiva brasileira. Rio de Janeiro: Renovar, 2001.

BARRETO, Luiz Paulo Teles. Das diferenças entre os institutos jurídicos do Asilo e do Refúgio. In httpp://www.mj.gov.br/snj/artigo_refugio.htm. Acesso em 06 nov. 2011.

BRASIL. Constituição (1988). Constituição da República Federativa do Brasil. Brasília, DF: Senado Federal, 1988.

HATHAWAY, James C. The rights of refugees under International Law. Cambridge: Cambridge University Press, 2005. 
Artigo original

Hegemonia - Revista Eletrônica de Relações Internacionais do Centro Universitário Unieuro

ISSN: $1809-1261$

UNIEURO, Brasília, número 9, 2012, pp. 4-30.

MELLO, Celso D. de Albuquerque. Curso de Direito Internacional Público. 15 ed. rev. ampl. vl. 2. Renovar. Rio de Janeiro, 2004.

MOREIRA, Júlia Bertino. "A Problemática dos Refugiados no Mundo:

Evolução do Pós-Guerra aos dias atuais." Campinas, 2006.

PIOVESAN, Flávia. O direito de asilo e a proteção internacional dos refugiados. In: ARAÚJO, Nádia de; ALMEIDA, Guilherme Assis de (Coord.). O Direito Internacional dos Refugiados: uma perspectiva brasileira. Rio de Janeiro: Renovar, 2001.

SANTIAGO, Jaime Ruiz de. Temas relevantes del Derecho Internacional de los Refugiados com respecto al problema de los refugiados en América Latina. Revista do Instituto Brasileiro de Direitos Humanos. Fortaleza: v. 1. no 1, 1999. 